\title{
Pendidikan Kesehatan tentang Gaya Hidup Sehat Pada Remaja Tahap Akhir
}

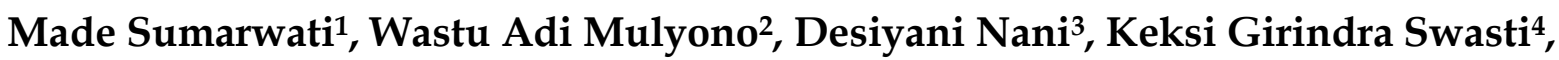 Haidar Amr Abdilah ${ }^{5}$}

\author{
1,2,3,4,5 Universitas Jenderal Soedirman Purwokerto \\ e-mail: ${ }^{1}$ made.sumarwati@unsoed.ac.id, ${ }^{2}$ wastu@unsoed.ac.id, \\ 32desiyani.nani@unsoed.ac.id, ${ }^{4}$ keksi.swasti@unsoed.ac.id, \\ 5haidar.abdillah@mhs.unsoed.ac.id
}

\begin{abstract}
Abstrak
Kondisi pandemi Covid-19 saat ini memberikan kesadaran bahwa kesehatan adalah suatu investasi yang menjadi fondasi dari ekonomi tangguh, stabil dan produktif. Sebagai investasi, semakin dini dilaksanakan, maka semakin besar manfaat yang diperoleh. Pengabdian ini ditujukan kepada kelompok remaja akhir untuk meningkatkan dan memampukan remaja membuat keputusan dengan penuh kesadaran memilih gaya hidup sehat. Metode yang diterapkan pada pengabdian ini adalah memberikan pendidikan kesehatan tentang gaya hidup sehat, meliputi berpikir dan membuat keputusan, olah raga, nutrisi, emosi, sosial dan spiritual. Pengabdian dilakukan selama periode satu bulan, diawali dengan analisis perilaku hidup sehat sehari-hari pada 68 peserta. Data menunjukkan $61,02 \%$ memiliki perilaku hidup sehat dengan kategori tinggi, dan 38,98\% berada pada kategori sedang-rendah; $62,71 \%$ memilih hidup sehat dengan $74.57 \%$ memiliki kepercayaan diri yang tinggi mampu melakukannya secara konsisten. Evaluasi dilakukan segera dan satu bulan setelah edukasi. Pendidikan kesehatan dilakukan secara daring. Setelah pendidikan kesehatan, $83,33 \%$ peserta memilih untuk menjalankan perilaku sehat dan $78,79 \%$ memiliki kepercayaan diri yang tinggi untuk menerapkannya secara konsisten. Evaluasi setelah satu bulan berikutnya ditemukan data bahwa masih terdapat perilaku hidup sehat kurang baik sebesar 3,33\%. Terjadi penurunan sedikit, baik dalam jumlah remaja yang memutuskan untuk memilih melakukan gaya hidup sehat $(75,76 \%)$ maupun kepercayaan diri $(73,33 \%)$. Kesimpulan dari pengabdian masyarakat ini adalah pendidikan kesehatan dapat membantu remaja akhir memutuskan untuk memilih gaya hidup sehat dan meningkatkan kepercayaan diri dalam mengimplementasikannya. Untuk lebih memaksimalkan hasil pendidikan, sangat disarankan melakukan kajian terkait kendala yang dihadapi remaja dalam menjalankan gaya hidup sehat sehingga bisa membangun program yang lebih sesuai.
\end{abstract}

Kata Kunci: Gaya Hidup Sehat, Remaja Akhir, Kepercayaan Diri. 


\begin{abstract}
The current conditions of the Covid-19 pandemic provide awareness that health is an investment that forms the foundation of a strong, stable, and productive economy. As an investment, the earlier it is done, the greater the benefits. The target was the late teenager, and the program aimed to help teenagers increase healthy lifestyles and consciously choose a healthy lifestyle. The method of this service was to provide education about a healthy lifestyle, including decision-making skills, exercise, nutrition, emotion, social, and spirituality. This service was carried out over one month, beginning with an analysis of the healthy lifestyle behavior of 68 participants. Data showed that $61.02 \%$ had healthy behavior in the high category, and $38.98 \%$ were in the medium-low category; $62,71 \%$ chose a healthy lifestyle, and $74.57 \%$ had high confidence performing it constantly. The evaluation was done immediately and one month after education. Health education was conducted online. After education, $83.33 \%$ of teenagers strongly decided to practice a healthy lifestyle, and 78,79\% possessed very high confidence to implement it continuously. Data after one month later found that 3.33\% of teenagers still had an unhealthy lifestyle. There was a slight decrease in the number of teenagers who decided to choose a healthy lifestyle $(75,76 \%)$ and confidence to apply it consistently (73,33\%). This community service concludes that health education can help late teenagers choose a healthy lifestyle and increase their confidence in implementing it. It is highly recommended to explore teenagers' barriers in practicing a healthy lifestyle to build more appropriate programs.
\end{abstract}

Keywords: Healthy Lifestyle, Late Teenager, Confidence.

\title{
Pendahuluan
}

\section{Latar Belakang}

Hampir setahun ini, pandemi Covid-19 yang merupakan masalah kesehatan, secara nyata memicu krisis sosial-ekonomi. Sekalipun tiap negara memiliki besaran dampak yang berbeda-beda, namun United Nations Development Programme (UNDP) mendapatkan data adanya kecenderungan peningkatan kemiskinan dan kesenjanganan ekonomi secara global (UNDP, 2020). Dampak tindakan mengisolasi diri untuk mencegah penyebaran virus dan menyelamatkan kehidupan menyebabkan disrupsi produksi masif yang menurunkan barang dan jasa sehingga mengurangi jam kerja dan jumlah pegawai. Hal ini secara nyata menyebabkan penurunan pendapatan dan meningkatkan pengangguran. Gambaran ini memperlihatkan adanya keterikatan antara kesehatan dan ekonomi. World Health Organization (WHO) menggambarkan bahwa kesehatan dan ekonomi saling bergantung satu sama lain (WHO, 2020). Walaupun saling bergantung satu sama lain, namun pandemi Covid ini, dengan berbagai dampaknya, hampir memperlihatkan bahwa kesehatan adalah di atas segalanya. Tanpa kesehatan, segala sesuatu tidak berjalan dengan baik. Keseluruhan situasi dan kondisi pandemi saat ini memberikan kesadaran bahwa kesehatan bukanlah sesuatu yang harus dibayar, tetapi lebih dipandang sebagai suatu investasi yang menjadi dasar atau fondasi dari ekonomi tangguh, stabil dan produktif(WHO, 2020). 
Investasi terbaik adalah memiliki kesehatan yang baik. Bentuk investasi ini tidak memiliki risiko, bahkan tersedia merata bagi semua orang. Investasi ini memiliki karakter semakin hari semakin berharga, serta terbukti menjadi pendorong karir dan menghemat biaya pengeluaran akibat penyakit sehingga biaya tersebut dapat digunakan untuk hal lainnya. Kesehatan yang baik dapat merupakan rejeki yang tak tertandingi oleh investasi keuangan apapun, baik itu uang maupun emas. Oleh karena itu penting bagi setiap orang untuk mulai melakukan investasi ini.

Sayangnya, kebanyakan orang seringkali lupa untuk melakukan investasi ini. Lupa untuk membangun dan memiliki kesehatan yang baik. Terlebih pada mereka yang berusia muda dimana tubuh secara fisiologis masih tumbuh dan berkembang, mudah untuk menyesuaikan diri dan masih menerima dampak positif dari usia yang bertambah. Bukan hanya lupa, tetapi juga malah melakukan aktivitas sehari-hari yang tidak mendukung kesehatan. Kesadaran untuk membangun dan memiliki kesehatan yang baik kadang datang terlambat. Hadirnya kesadaran tersebut ketika masalah kesehatan sudah terjadi, dengan kata lain ketika sudah sakit.

Aktivitas sehari-hari yang mendukung kesehatan dan dilakukan secara rutin dikenal dengan sebutan gaya hidup sehat (Healthy Lifestyle). Gaya hidup sehat ini mencakup berpikir (Thinking,), emosi (Emotions), bergerak dan olah raga (Exercise), nutrisi (Nutrition) dan aspek sosial serta spiritual (Melnyk et al., 2013). Gaya hidup sehat ini berhubungan dengan penurunan semua penyebab kematian, dan peningkatan umur dan kesejahteraan hidup (Larsson et al., 2017). Gaya hidup sehat juga memberikan kesempatan untuk mandiri lebih lama pada masa lanjut usia.

Mengadopsi gaya hidup sehat adalah sebuah pilihan. Hal ini sama seperti memilih gaya hidup lainnya, seperti hidup menetap atau nomaden, vegetarian atau tidak, hidup dengan gaya minimal atau berlebih. Saat dewasa, keputusan untuk hidup sehat hampir sepenuhnya merupakan keputusan masing-masing individu. Penelitian yang berfokus pada teori self-determination menunjukkan bahwa keputusan pribadi memberikan perubahan perilaku yang relatif permanen (Ryan \& Deci, 2000). Dengan demikian maka perubahan yang terjadi karena adanya tekanan seperti rasa bersalah atau karena rasa takut maka perubahan tidak akan terjadi sesuai yang diharapkan.

Solusi dalam memiliki gaya hidup sehat sehingga seseorang memiliki kesehatan yang baik adalah dengan membantu menumbuhkan kesadaran akan perlunya memiliki gaya hidup yang sehat. Melalui pemahaman yang baik, diharapkan lahir pemikiran positif yang memotivasi diri untuk melakukan aktivitas merawat kesehatan yang baik. Harapan yang lebih jauh adalah aktivitas yang sehat itu dilakukan secara rutin, sehingga aktivitas itu akan berubah menjadi perilaku dan kemudian menjadi gaya hidupnya sehari-hari. Bentuk kegiatan yang mendukung solusi ini adalah dengan memberikan pendidikan kesehatan tentang gaya hidup sehat sebagai fondasi memiliki masa depan yang lebih baik. Untuk meningkatkan pemahaman maka dampak Covid-19 sebagai masalah kesehatan pada aspek sosial 
dan ekonomi akan dijadikan media untuk menstimulasi ketertarikan akan perlunya memiliki investasi kesehatan yang dibangun dari gaya hidup sehat. Pengintegrasian seluruh aspek ini akan mempromosi terbentuknya gaya hidup sehat (Rahayu et al., 2019)

Pendidikan tentang gaya hidup sehat diperlukan sedini mungkin sejak usia anakanak. Tetapi, untuk mampu mengkaitkan kebutuhan kesehatan dengan masa depan diperlukan kemampuan berpikir abstrak, sehingga baik diberikan pada kelompok remaja akhir. Remaja akhir adalah kelompok usia 17 - 20 tahun, merupakan kelompok yang lebih stabil dan mampu berdiskusi terkait ekonomi, keuangan dan rencana masa depan (Berman et al., 2016). Kelompok ini sesaat lagi akan memasuki usia dewasa dimana keputusan-keputusan secara mandiri akan dibuatnya. Dengan memiliki pengetahuan gaya hidup yang baik diharapkan remaja akan memutuskan secara mandiri dengan penuh kesadaran untuk memiliki gaya hidup sehat yang merupakan fondasi penting bagi kehidupan ekonominya di masa depan.

\section{Tujuan Pengabdian}

Tujuan pengabdian ini adalah untuk meningkatkan gaya hidup sehat dan memampukan remaja akhir membuat keputusan memilih hidup sehat dengan penuh kesadaran serta memiliki kepercayaan diri melakukannya secara rutin.

\section{Manfaat Pengabdian}

Pengabdian Kepada Masyarakat ini memiliki tiga manfaat. Adapun ketiga manfaat tersebut yaitu 1. Pengabdian ini memenuhi kebutuhan remaja akhir akan pengetahuan, keterampilan dan informasi gaya hidup sehat untuk memampukannya membuat keputusan seberapa besar kesehatan yang akan dicapainya; 2. Pengabdian ini membantu remaja akhir untuk mendapat gambaran jelas maksud dari gaya hidup sehat sebagai investasi di kehidupan masa depan, mengingat gaya hidup sehat terbukti secara ilmiah menurunkan semua penyebab kematian, dan meningkatkan kualitas hidup sehingga kesejahteraan dapat tercapai sekaligus memberikan kesempatan untuk mandiri lebih lama pada masa tua; 3. Pengetahuan pemanfaatan sumber-sumber yang tersedia, seperti keadaan lingkungan tempat tinggal, waktu, persahabatan, dan dukungan sosial lainnya menstimulasi remaja untuk mendapatkan gambaran bahwa gaya hidup sehat bukan mustahil untuk dimiliki.

\section{Kajian Pustaka}

Gaya hidup sehat memiliki banyak dimensi, bukan hanya terbatas pada perawatan tubuh yang melibatkan diet dan olah raga. Gaya hidup sehat didefinisikan sebagai pola tindakan dalam mempertahankan atau meningkatkan kesehatan yang dibentuk melalui aktivitas fisik yang teratur, tidak merokok, berat badan yang ideal, dan menjaga pola makan tetap (Balanzá-Martínez et al., 2020).

Dimensi gaya hidup sehat meliputi kesehatan fisik, psikis, sosial dan spiritual (Bagheri \& Gharehbaghi, 2019). Kesehatan fisik meliputi bebas dari sakit, memiliki cukup energi, vitalitas dan merasa sehat. Dalam dimensi fisik, untuk mendapatkan 
kesehatan, energi dan kehidupan produktif maka perlu melakukan aktivitas fisik secara reguler. Aktivitas fisik didefinisikan sebagai gerakan tubuh akibat gerakan otot rangka yang menghasilkan pengeluaran energi, dan mencakup gerakan saat melakukan pekerjaan, dan kegiatan rutin sehari-hari serta di waktu senggang (Pender et al., 2015). Olah raga adalah bagian dari aktivitas fisik yang dilakukan pada waktu senggang, yang dilakukan secara terjadwal, terstruktur, berulang dan ditujukan untuk meningkatkan dan mempertahankan kebugaran. Aktivitas fisik yang teratur dapat meningkatkan kesehatan mental, meningkatkan kemampuan seseorang untuk melakukan tugas sehari-hari dengan lebih baik, dan berfungsi sebagai terapi tambahan dalam gangguan kesehatan mental (Meng \& D'Arcy, 2013).

Dimensi sehat kedua adalah terkait nutrisi. Peran nutrisi saat ini menjadi sangat luas, mulai dari nilai gizi yang diperlukan atau angka kecukupan nutrisi, sampai perannya dalam mempromosi kesehatan dan pencegahan penyakit. Gaya hidup sehat terkait nutrisi dan pola makan meliputi makan secara teratur dengan porsi lebih besar pada sayuran dan buah yang mengandung vitamin, mineral dan serat; mengkonsumsi lebih sedikit makanan yang mengandung lemak dan gula (Michaelsen \& Esch, 2021; Pender et al., 2015). American Heart Association juga merekomendasikan untuk mengkonsumsi ikan setidaknya dua kali dalam seminggu, terutama ikan yang memiliki kandungan asam lemak omega-3 (sarden, makarel, atau salmon). Gaya hidup sehat juga digambarkan dengan mengunyah makanan dengan baik. Para ahli gizi mengingatkan bahwa sebaiknya makanan sebelum ditelan dikunyah sebanyak 20-30 kali agar makanan siap dicerna tubuh dengan baik. Hal lain yang merupakan gaya hidup terkait nutrisi adalah menghindari pemanis artifisial karena telah terbukti pemanis buatan berkaitan dengan peningkatan risiko obesitas, diabetes, hipertensi dan penyakit jantung (Ashton et al., 2017)

Kesehatan psikis meliputi kemampuan berpikir jernih, mampu beradaptasi dan memiliki resiliensi, mengenali, mengekspresikan dan mengendalikan stres, serta mampu bersikap asertif. Gaya hidup sehat pada dimensi psikis mencakup pencegahan stres dan pengembangan kemampuan menyelesaikan masalah (Pender et al., 2015; Stuart, 2013). Pada dimensi ini arah gaya hidup sehat ditekankan pada kemampuan menyelesaikan masalah dan mengembangkan kemampuan menanggulasi stress akibat masalah serta mampu beradaptasi pada berbagai situasi.

Dimensi kesehatan sosial meliputi membangun hubungan sosial yang bermakna. Gaya hidup pada dimensi sosial ini diarahkan pada kebiasaan berkomunikasi dan mengembangkan kemampuan membina dan mempertahankan hubungan interpersonal. Hubungan antar individu, atau individu dan kelompok diarahkan untuk membentuk dukungan sosial. Dukungan sosial digambarkan sebagai jaringan hubungan interpersonal yang memberikan sumber-sumber material dan psikologikal yang diarahkan untuk membangun kemampuan mengatasi tekanan masalah (Goldman \& Cojocaru, 2017; Pender et al., 2015). Dukungan sosial ini mencakup dukungan emosi berupa perhatian, empati, cinta dan rasa percaya; dukungan instrumental mencakup bantuan pemenuhan material dan jasa; dukungan 
informational mengacu pada pemberian nasihat, saran dan informasi personal lainnya; dan dukungan appraisal yang merupakan pemberikan afirmasi atau umpan balik yang konstruktif. Dukungan ini bekerja pada situasinya masing-masing untuk mengatasi keadaan negatif (Szkody et al., 2021).

Kesehatan spiritual merupakan komponen yang tidak dapat dipisahkan dalam filosofi kesehatan yang holistik (Hsiao et al., 2010). Bersama kondisi fisik dan mental, spiritual memberikan arah dan makna dalam kehidupan. Spiritual berkaitan dengan nilai dan keyakinan yang terintegrasi dalam setiap hal baik dalam kehidupan sosial maupun pekerjaan. Praktik keagamaan merupakan sistem keyakinan spiritual yang terorganisir dan memiliki cara-cara khusus untuk mengekspresikannya (Miller \& Zucchini, 2013). Gaya hidup pada aspek ini mencakup kebiasaan mengidentifikasi segala sesuatu yang memberikan rasa damai, tenang, kuat, kasih, dan memiliki harapan (Bagheri \& Gharehbaghi, 2019). Hal lain dalam Kesehatan spiritual adalah memiliki koneksi dengan sesama manusia dan Yang Maha Tinggi; serta memiliki waktu untuk melakukan kegiatan praktik keagamaan termasuk ritual, ibadah, ketaatan pada hal yang diperbolehkan dan tidak diperbolehkan, terlibat dalam kegiatan kerohanian, membaca buku-buku terkait, dan memiliki waktu untuk introspeksi/refleksi diri (Aksoy et al., 2017).

\section{Metode}

\section{Tahap Persiapan}

Sebelum melaksanakan kegiatan, beberapa persiapan dilakukan. Persiapan meliputi diskusi menetapkan tujuan yang ingin dicapai, bentuk kegiatan dan target peserta. Diskusi menyepakati bentuk kegiatan adalah pendidikan kesehatan dengan target peserta adalah siswa SMA di wilayah Banyumas, usia 17-18 tahun. Pada tahap ini, tim melakukan koordinasi penyelenggaraan kegiatan dengan pihak sekolah dan mengundang 100 siswa untuk menghadiri pendidikan kesehatan tentang gaya hidup sehat.

\section{Tahap Pelaksanaan}

Kegiatan dilakukan dalam tiga tahap. Tahap pertama adalah pengkajian terkait perilaku hidup sehat yang dijalani sehari-hari, pemilihan gaya hidup dan tingkat kepercayaan diri dalam menjalankan pilihan gaya hidup sehat. Pengkajian dilakukan pada tanggal 15 Juni 2021 dengan mengirimkan kuesioner melalui Google form. Tahap kedua adalah pelaksanaan pendidikan kesehatan. Beberapa aspek materi dikembangkan berdasarkan hasil pengkajian yang diperoleh. Pertemuan dilakukan secara daring pada tanggal 17 Juni 2021. Pertemuan dihadiri oleh seluruh pengabdi berjumlah 5 orang, ibu kepala sekolah, guru, dan siswa. Jumlah kehadiran dari guru dan siswa sebanyak 68 orang. Acara dibagi menjadi 3 sesi berisikan pemberian materi diikuti dengan sesi tanya jawab. Isi pendidikan kesehatan dapat dilihat di Tabel 1. Tahap ketiga adalah evaluasi. Evaluasi dilakukan segera (17 Juni 2021) dan setelah satu bulan setelah edukasi diberikan (9 Juli 2021). Data yang diperoleh pada pengabdian ini dianalisa dengan menggunakan persentase. 


\section{Hasil dan Pembahasan}

Survei mengenai gaya hidup sehat yang dilakukan sehari-hari disampaikan kepada 100 remaja dan mendapat respon secara sukarela dari 59 peserta (32,2\% remaja putra dan $67,8 \%$ remaja putri). Pelaksanaan kegiatan dilakukan secara daring dengan mengundang 100 peserta dan dihadiri oleh 69 peserta. Agar acara dapat diakses secara baik, maka setiap peserta mendapatkan bantuan pulsa yang diberikan sebelum acara berlangsung.

Materi mencakup 6 sub topik (Tabel 1). Topik proses berpikir, keterampilan berpikir kritis untuk membuat keputusan diberikan pada sesi pertama. Topik ini mengantarkan peserta untuk secara rutin menggunakan langkah-langkah membuat keputusan secara ilmiah dan logis. Hal ini menjadi dasar bagi peserta dalam memilih gaya hidup. Pemilihan gaya hidup adalah keputusan personal yang dilakukan secara sadar untuk menjalankan perilaku yang meningkatkan atau menurunkan risiko terjadinya masalah kesehatan (Lifestyle Choices and Personal Wellness: Decisions, Behavior \& Prevention, 2014)

Tabel 1. Materi Pendidikan Kesehatan Gaya Hidup Sehat bagi Remaja

\begin{tabular}{|l|l|l|}
\hline No & Topik & Isi Materi \\
\hline \multirow{2}{*}{1.} & $\begin{array}{l}\text { Berpikir dan } \\
\text { membuat keputusan }\end{array}$ & Proses berpikir, menetapkan tujuan dan menyelesaikan masalah \\
\hline 2. & Emosi & Stress and Coping Mechanism \\
\hline 3. & Aktivitas fisik & Aktivitas fisik dan berolah raga \\
\hline \multirow{3}{*}{4.} & \multirow{3}{*}{ Nutrisi } & Makanan ringan dan jajan \\
\cline { 3 - 3 } & & Makanan dan kesehatan. Stoplight diet: red, yellow, and green. \\
\cline { 3 - 3 } & & $\begin{array}{l}\text { Nutrisi bagi kesehatan. Membaca label makanan. Efek media } \\
\text { pada pemilihan makanan. }\end{array}$ \\
\cline { 3 - 3 } & & Porsi sehat dan Pengaruh emosi pada pola makan. \\
\hline 5. & Sosial & Membangun kehidupan sosial \\
\hline 6. & Spiritual & Membangun kehidupan spiritual yang baik \\
\hline
\end{tabular}

Hasil survei gambaran gaya hidup sehat sebelum dan setelah pendidikan kesehatan dapat dilihat dari Tabel 2. Pada tabel tersebut dapat dilihat bahwa data awal menunjukkan perilaku hidup sehat yang sangat tinggi terdapat pada dimensi spiritual. Penguatan pada pelatihan memberikan kenaikan prosentase dari $91.53 \%$ menjadi $96.67 \%$. Data ini menunjukkan remaja telah menerapkan gaya hidup sehat dimensi spiritual dengan sangat baik. Banyak penelitian menyatakan bahwa spiritual yang baik melindungi remaja dari berbagai hal-hal yang buruk. Remaja dengan spiritual tinggi adalah remaja yang sopan (Jochman, 2019), tidak melakukan penyalahgunaan obat, seks bebas, dan tidak melakukan tindakan destruktif lainnya (Hayward, 2019). Selain itu, spiritual yang baik memberikan remaja keuntungan lain seperti menurunkan kecemasan dan stres, meningkatkan interaksi sosial dengan teman, memiliki teman yang memberikan pengaruh positif dan memberikan kesuksesan pada tahap perkembangan berikutnya (Hsiao et al., 2010). 
Jurnal Pengabdian Kepada Masyarakat

Tabel 2. Gaya Hidup Sehat Remaja Sebelum dan 1 Bulan Setelah Pendidikan Kesehatan

\begin{tabular}{|l|c|c|c|c|c|c|}
\hline \multirow{2}{*}{$\begin{array}{c}\text { Aspek Gaya Hidup } \\
\text { Sehat }\end{array}$} & \multicolumn{2}{|c|}{ Baik (\%) } & \multicolumn{2}{c|}{ Sedang (\%) } & \multicolumn{2}{c|}{ Buruk (\%) } \\
\cline { 2 - 7 } & Sebelum & $\begin{array}{c}\text { 1 Bulan } \\
\text { Setelah }\end{array}$ & Sebelum & $\begin{array}{c}\text { 1 Bulan } \\
\text { Setelah }\end{array}$ & Sebelum & $\begin{array}{c}\text { 1 Bulan } \\
\text { Setelah }\end{array}$ \\
\hline Spiritual & 91,53 & 96,67 & 6,78 & 3,33 & 0,00 & 0,00 \\
\hline Emosi & 69,49 & 83,33 & 28,81 & 16,67 & 1,69 & 0,00 \\
\hline Sosial & 28,81 & 53,33 & 69,49 & 33,33 & 1,69 & 0,00 \\
\hline Aktivitas fisik & 38,98 & 40,00 & 40,68 & 46,67 & 20,34 & 13,33 \\
\hline Nutrisi & 20,34 & 26,67 & 54,24 & 56,67 & 25,42 & 16,67 \\
\hline
\end{tabular}

Gaya hidup remaja yang juga berada pada kategori baik adalah pada dimensi emosi. Dimensi emosi ini meliputi pengendalian diri, mekanisme menanggulasi stress akibat masalah, kemampuan memahami persoalan dan menyelesaikan masalah. Semua peristiwa yang terjadi sepanjang hidup individu dapat meningkatkan risiko terjadinya masalah pada individu tersebut (Stuart, 2013). Data awal memperlihatkan hampir 70\% remaja memiliki kemampuan yang baik dalam mengendalikan emosi. Pendidikan kesehatan memberikan pemaparan dan contoh-contoh dari upaya mengatasi stres melalui mekanisme penanggulangan stres yang berorientasi pada tugas (task oriented) dan yang berorientasi pada emosi (ego oriented). Edukasi materi ini memberikan peningkatan sehingga setelah satu bulan, seluruh remaja berada pada rentang sedang - tinggi.

Mayoritas remaja akhir berada pada rentang sedang pada dimensi sosial. Dimensi ini meliputi interaksi remaja dengan teman dan keluarga dalam memberi dan menerima dukungan sosial. Dukungan sosial digambarkan sebagai jaringan hubungan antar pribadi yang menyediakan sumber daya baik psikologis dan maupun material untuk mengatasi keadaan yang tidak terduga, sulit, atau mengancam (Pender et al., 2015). Ini adalah fungsi hubungan sosial yaitu membangun dukungan sosial yang kuat. Pada masa pandemi Covid, terbukti dukungan sosial dapat melawan efek negatif dari stres yang ditimbulkan akibat perlunya isolasi mandiri (Szkody et al., 2021). Remaja membutuhkan seluruh dukungan jenis dukungan ini. Sumber dukungan pertama remaja adalah orang tua yang memberikan dukungan emosional, instrumental, informasi, dan appraisal atau afirmasi, selanjutnya adalah sahabat karib. Pendidikan kesehatan ini memberikan kesadaran bahwa meningkatkan relasi yang baik dengan orang tua dan membangun persahabatan adalah hal yang penting sebagai investasi dalam pemberian dukungan sosial yang masa yang akan datang.

Pada dimensi aktivitas fisik, ada sepertiga remaja akhir yang melakukannya secara rutin, berolah raga sampai berkeringat minimal 20 menit sehari atau 150 menit per 
minggu dan tetap aktif di waktu libur atau senggang. Data sebelum edukasi menunjukkan terdapat 20,34\% remaja dengan kategori buruk. Beberapa penelitian menemukan bahwa remaja memiliki banyak kendala dalam mengadopsi dimensi ini. Kendala tersebut diantaranya adalah kurang motivasi, kesibukan/tidak tersedia waktu dan biaya bila mengikuti klub olah raga (Ashton et al., 2017), kurangnya fasilitas dan dukungan dari orang tua/keluarga (Shahsanai et al., 2019). Pendidikan kesehatan yang diberikan oleh tim memberikan dampak positif namun setelah satu bulan setelah edukasi masih menyisakan remaja dengan kategori buruk sebesar $13,33 \%$. Upaya meningkatkan remaja mengadopsi beraktivitas fisik yang baik tidak cukup hanya dengan pendidikan kesehatan, tetapi perlu dikembangkan materi yang mencakup aspek sosial budaya yang dianut remaja. Hal ini mengingat karakteristik remaja, dimana ada kemungkinan merasa malu akan penampilannya saat berolahraga atau kendala lainnya berdasarkan budaya yang dianut (Ashton et al., 2017). Untuk mengetahuinya maka pengkajian seperti menggali sumber-sumber motivasi dan kendala beraktivitas fisik perlu dilakukan.

Pada dimensi nutrisi, terjadi peningkatan sedikit setelah pendidikan kesehatan dilakukan. Banyak faktor yang mempengaruhi remaja untuk bisa memiliki gaya hidup yang baik pada dimensi ini, diantaranya adalah orang tua, teman sebaya, media dan guru (Shahsanai et al., 2019). Kendala utama adalah ketersediaan makanan sehat dan hal ini berkaitan dengan sosial ekonomi keluarga, kurang informasi orang tua terkait nutrisi dan makanan sehat dan rendahnya motivasi orang tua dalam menyiapkan makanan sehat (Ashton et al., 2017). Pada analisis dan evaluasi akhir, diketahui remaja tidak memiliki kebiasaan menghitung kalori dan membaca label komposisi makanan pada kemasan makanan. Tidak melakukan hal ini lebih diakibatkan karena remaja tidak biasa menghitung berapa kebutuhan kalori yang diperlukan perhari. Saat edukasi, topik menghitung kalori, baik untuk upaya mempertahankan, menaikan, atau menurunkan berat badan sangat menarik perhatian peserta, ditandai dengan adanya penambahan waktu diskusi. Hal ini menjadi catatan khusus dalam memberikan pendidikan kesehatan terkait nutrisi, sangat perlu memiliki data rata-rata status gizi peserta, minimal tinggi badan dan berat badan, sehingga dapat memperoleh gambaran kebutuhan dan minat secara lebih detail. Untuk meningkatkan keberhasilan pendidikan, mirip seperti aktivitas fisik, pengkajian terkait sosial budaya perlu dilakukan seperti apa yang menjadi motivasi menjaga berat badan dan kendala dalam menerapkan pola makan sehat. Seluruh informasi ini akan membantu untuk membangun materi dan media yang lebih memenuhi kebutuhan remaja.

Pada Tabel 3, data sebelum pendidikan kesehatan menunjukkan bahwa 61,02 remaja memiliki gaya hidup sehat yang tinggi dan meningkat setelah satu bulan berikutnya. Sekalipun terjadi peningkatan, namun masih menyisakan 3,33\% remaja yang memiliki gaya hidup sehat yang rendah. Pada remaja yang ikut serta dalam pengabdian ini, gaya hidup sehat yang sulit diadopsi adalah dimensi beraktivitas fisik rutin dan asupan nutrisi yang sehat. Dalam masa dimana komputer, telepon genggam dan kemajuan teknologi lainnya mendominasi maka dapat dipahami 
bahwa memiliki gaya hidup sehat, terutama terkait aktivitas fisik rutin merupakan hal yang sulit dilakukan. Khusus aspek nutrisi, seringkali menurut takaran remaja makanan sehat dirasa kurang gurih, mahal dan sulit untuk diperoleh dibandingkan makanan cepat saji (Lems et al., 2020). Hal ini memperlihatkan bahwa sekalipun sejumlah manfaat dari hidup sehat dijabarkan dengan baik dan teliti, namun data hasil pengabdian ini menunjukkan bahwa berubah memiliki gaya hidup yang baik lebih mudah diutarakan daripada dilakukan. Fakta memperlihatkan memilih hidup sehat berarti membangun disiplin (Lems et al., 2020). Perlu kesadaran kuat dan dukungan lingkungan untuk mendisiplinkan diri dan berubah dari kebiasaan yang lama ke kebiasaan yang lebih sehat.

Tabel 3. Gaya Hidup Sehat, Besaran Keputusan dan Keyakinan Menjalankan Gaya Hidup Sehat Secara Rutin Sebelum, Setelah dan 1 Bulan Setelah Pendidikan Kesehatan

\begin{tabular}{|l|c|c|c|c|c|c|c|c|c|}
\hline \multirow{2}{*}{ Aspek } & \multicolumn{3}{|c|}{ Tinggi (\%) } & \multicolumn{3}{c|}{ Sedang (\%) } & \multicolumn{3}{c|}{ Rendah (\%) } \\
\cline { 2 - 10 } & Sebelum & Setelah & $\begin{array}{c}1 \\
\text { bulan }\end{array}$ & Sebelum & Setelah & $\begin{array}{c}1 \\
\text { bulan }\end{array}$ & Sebelum & Setelah & $\begin{array}{c}1 \\
\text { bulan }\end{array}$ \\
\hline $\begin{array}{l}\text { Gaya hidup } \\
\text { sehat }\end{array}$ & 61,02 & - & 73,33 & 25,42 & - & 23,33 & 13,56 & - & 3,33 \\
\hline $\begin{array}{l}\text { Memilih } \\
\text { gaya hidup } \\
\text { sehat }\end{array}$ & 62,71 & 83,33 & 75,76 & 28,81 & 16,67 & 24,24 & 8,47 & 0,00 & 0,00 \\
\hline $\begin{array}{l}\text { Kepercayaan } \\
\text { diri }\end{array}$ & 74,57 & 78,79 & 73,33 & 20,34 & 21,21 & 26,67 & 5,08 & 0,00 & 0,00 \\
\hline
\end{tabular}

Secara umum mayoritas peserta memilih memiliki gaya hidup sehat. Pemilihan tertinggi terlihat sesaat setelah pendidikan kesehatan diberikan. Pendidikan kesehatan ini memenuhi kebutuhan peserta akan informasi risiko dan manfaat memiliki gaya hidup sehat. Persepsi akan kendala dan pengalaman yang dialami mempengaruhi peserta pada kepercayaan diri dalam menjalankannya secara terus menerus. Kelompok yang memiliki kepercayaan diri dalam kategori sedang dan rendah, cenderung berfokus pada kesulitan dan keterbatasan diri (Ashton et al., 2017). Menyikapi hal ini, remaja perlu membuat capaian perubahan secara bertahap dengan mempertimbangkan keterampilan dan kemampuan yang dimilikinya, sehingga mempertahankan dan meningkatkan perilaku sehat bukan hal yang mustahil untuk dimiliki.

Memiliki gaya hidup sehat bukan hanya proses sesaat, oleh karena itu tindak lanjut dari pengabdian ini perlu dikembangkan. Aktivitas lanjutan dari pendidikan kesehatan ini adalah menguatkan perubahan yang telah dicapai. Setelah memiliki pilihan gaya hidup sehat, langkah berikutnya adalah menetapkan rencana dilanjutkan dengan inisiasi atau implementasi (Michaelsen \& Esch, 2021). Pada saat inisiasi perilaku sehat, hal yang harus diperhatikan dan dirasakan adalah dampak positif dari perilaku tersebut. Memperhatikan dan merasakan dampak positif ini akan mendorong tindakan repetitif dan terus berlanjut sehingga perubahan yang diharapkan menjadi bagian dari gaya hidupnya sehari-hari. Salah satu cara 
mempermudah dan meningkatkan keberhasilan membangun gaya hidup sehat adalah dengan membangun tiap dimensi sehat satu per satu (Bigelow, 2019).

\section{Simpulan dan Rekomendasi}

Secara umum pendidikan kesehatan membantu meningkatkan kemampuan remaja untuk memilih memiliki hidup sehat dan meningkatkan kepercayaan remaja dalam menjalankannya secara konsisten. Langkah selanjutnya adalah melakukan kegiatan untuk menguatkan perubahan yang telah dicapai, diantaranya dengan mempertahankan komunikasi dan melakukan evaluasi berkala akan dampak positif yang diperoleh dari perilaku sehat yang dilakukan. Untuk meningkatkan keberhasilan sangat disarankan untuk melakukan kajian terkait kendala dan gambaran sosial budaya yang dianut remaja sehingga dengan hasil kajian tersebut dapat dibangun program yang sesuai kebutuhan.

\section{Perhargaan}

Tim pengabdi ingin menucapkan terimakasih kepada LPPM Universitas Jenderal Soedirman melalui Program Penerapan Ipteks tahun 2021 sehingga kegiatan pengabdian kepada masyarakat ini dapat dilaksanakan. Tim pengabdi juga mengucapkan terima kasih yang sebesar-besarnya kepada remaja dan guru pembimbing yang turut berpartisipasi dalam pengabdian masyarakat ini.

\section{Daftar Pustaka}

Aksoy, M., Ipek Coban, G., \& Professor, A. (2017). Nursing students' perceptions of spirituality and spiritual care. In International Journal of Caring (Vol. 10). www.internationaljournalofcaringsciences.org

Ashton, L. M., Hutchesson, M. J., Rollo, M. E., Morgan, P. J., \& Collins, C. E. (2017). Motivators and barriers to engaging in healthy eating and physical activity: A cross-sectional survey in young adult men. American Journal of Men's Health, 11(2). https:// doi.org/10.1177/1557988316680936

Bagheri, F., \& Gharehbaghi, F. (2019). The Relationship between Mindfulness, Happiness and Healthy Lifestyle. Caspian Journal of Health Research, 4(2), 44-48. https://doi.org/10.29252/cjhr.4.2.44

Balanzá-Martínez, V., Atienza-Carbonell, B., Kapczinski, F., \& de Boni, R. B. (2020). Lifestyle behaviours during the COVID-19 - time to connect. In Acta Psychiatrica Scandinavica (Vol. 141, Issue 5). https:/ / doi.org/10.1111/acps.13177

Berman, A. T., Snyder, C., \& Frandsen, G. (2016). Kozier \& ERB'S Fundamentals of nursing: Concepts, process, and practice. In Pearson Education Inc.

Bigelow, D. (2019). Healthy habits suck: How to get off the couch and live a healthy life...Even if you don't want to (Vol. 144). New Harbinger Publications, Inc. 
Goldman, I., \& Cojocaru, S. (2017). The need for social support among nursing preceptors. Social Research Reports, 9, 7-21. www.indexcopernicus.com

Hayward, G. M. (2019). Religiosity and premarital sexual behaviors among adolescents: An analysis of functional form. Journal for the Scientific Study of Religion, 58(2), 439-458.

Hsiao, Y. C., Chiang, H. Y., \& Chien, L. Y. (2010). An exploration of the status of spiritual health among nursing students in Taiwan. Nurse Education Today, 30(5). https://doi.org/10.1016/j.nedt.2009.05.001

Jochman, J. C. (2019). Religious predictors of bully involvement in youth: An analysis using the national study of youth and religion. Conference Papers -- American Sociological Association, 1-49.

Larsson, S. C., Kaluza, J., \& Wolk, A. (2017). Combined impact of healthy lifestyle factors on lifespan: Two prospective cohorts. Journal of Internal Medicine, 282(3). https://doi.org/10.1111/joim.12637

Lems, E., Hilverda, F., Sarti, A., van der Voort, L., Kegel, A., Pittens, C., Broerse, J., \& Dedding, C. (2020). 'McDonald's is good for my social life'. Developing health promotion together with adolescent girls from disadvantaged neighbourhoods in amsterdam. Children and Society, 34(3), 204-219. https://doi.org/10.1111/chso.12368

Lifestyle choices and personal wellness: decisions, behavior E prevention. (2014, March 26). Https://Study.Com/Academy/Lesson/Lifestyle-Choices-and-PersonalWellness-Decisions-Behavior-Prevention.Html.

Melnyk, B. M., Jacobson, D., Kelly, S., Belyea, M., Shaibi, G., Small, L., O'Haver, J., \& Marsiglia, F. F. (2013). Promoting healthy lifestyles in high school adolescents: A randomized controlled trial. American Journal of Preventive Medicine, 45(4). https:/ / doi.org/10.1016/j.amepre.2013.05.013

Meng, X., \& D'Arcy, C. (2013). The projected effect of increasing physical activity on reducing the prevalence of common mental disorders among Canadian men and women: A national population-based community study. Preventive Medicine, 56(1). https://doi.org/10.1016/j.ypmed.2012.11.014

Michaelsen, M. M., \& Esch, T. (2021). Motivation and reward mechanisms in health behavior change processes. In Brain Research (Vol. 1757). https:/ / doi.org/10.1016/j.brainres.2021.147309

Miller, C. A. , \& Zucchini, M. (2013). Fast facts for health promotion in nursing. Springer Publishing Company. 
Pender, N. J., Murdaugh, C. L., \& Parson, M. A. (2015). Health promotion in nursing practice (7th ed.). Pearson.

Rahayu, E., Setiyani, R., Sumarwati, M., \& Kusumawardani, L. H. (2019). Positive correlation betwen self efficacy and health promoting lifestyle behavior of students of nursing department of Jenderal Soedirman University. Annals of Tropical Medicine and Public Health, 22(11). https://doi.org/10.36295/ASRO.2019.221132

Ryan, R. M., \& Deci, E. L. (2000). Self-determination theory and the facilitation of intrinsic motivation, social development, and well-being. American Psychologist, 55(1), 68-78.

Shahsanai, A., Bahreynian, M., Fallah, Z., Hovsepian, S., \& Kelishadi, R. (2019). Perceived barriers to healthy lifestyle from the parental perspective of overweight and obese students. Journal of Education and Health Promotion, 8(1). https://doi.org/10.4103/jehp.jehp_184_18

Stuart, G. W. (2013). Principles \& practice of psychiatric nursing (10th ed.). Elsevier Mosby.

Szkody, E., Stearns, M., Stanhope, L., \& McKinney, C. (2021). Stress-buffering role of social support during COVID-19. Family Process, 60(3). https://doi.org/10.1111/famp.12618

UNDP. (2020). Socio-economic impact of Covid-19. Https:/ /Www.Undp.Org/Content/Undp/En/Home/Coronavirus/SocioEconomic-Impact-of-Covid-19.Html.

WHO. (2020). WHO-establishes-council-on-the-economics-of-health-for-all. https://www.who.int/news/item/13-11-2020-who-establishes-council-on-theeconomics-of-health-for-all 